\title{
Cardiac Echinococcosis Involving Left Ventricular Myocardium in an 18-Year-Old Patient
}

\author{
Zaprin G. Vazhev, Hristo A.Stoev \\ Department of Cardiovascular Surgery, Medical University of Plovdiv, Plovdiv, Bulagaria
}

\section{Correspondence:}

Hristo A. Stoev, Department of Cardiovascular Surgery, Medical University of Plovdiv, 66 Peshtersko shosse Blvd. , 4000 Plovdiv, Bulgaria E-mail: hristostoev87@gmail.com Tel: +359 897336168

Received: 06 Jan 2017

Accepted: 26 July 2017

Published Online: 25 Sept 2017

Published: 30 June 2018

Key words: hydatid disease, cardiac hydatid disease, echocardiography, surgical treatment

Citation: Vazhev ZG, Stoev HA. Cardiac echinococcosis involving left ventricular myocardium in an 18-year-old patient. Folia Med (Plovdiv) 2018;60(2):308-13.

doi: 10.1515/folmed-2017-0081
The hydatid disease is one of the most common tapeworm infections. It is caused most commonly by Echinococcus granulosus and has an endemic distribution. The transmission to humans, which are intermediate hosts, occurs by ingestion of contaminated food and water or by direct contact with infected animals. Involvement of heart and pericardium is an extremely rare condition.

We present a case of an 18-year-old female patient, admitted in cardiology department complaining of chest pain and subfebrility. Transthoracic echocardiography and contrast enhanced CT revealed huge well-organized intramyocardial cyst in the lateral left ventricular wall with a few daughter cysts. The diagnosis of cardiac echinococcosis was confirmed by serological blood test - ELISA. We performed total resection of the cyst using extracorporeal circulation. The postoperative period was uneventful. Albendazole treatment was administered. The patient was followed-up one year with good postoperative result without any signs of relapse of the disease.

Cardiac hydatid disease is rarity, but it is a life-threatening condition because of the high risk of cyst perforation. Early diagnosis and treatment are crucial. Echocardiographic findings are extremely valuable for diagnosis. The results of surgical echinococcectomy combined with oral antihelmintic therapy postoperatively are preferred rather than conservative strategy alone.

\section{INTRODUCTION}

Echinococcosis is a disease that has been recognized since ancient times. The disease was reported by many ancient authors with contribution to medicine as Hippocrates, Aretes, Galen and Rhazes. Hippocrates described tumors filled with fluid, located in the internal organs, which he found in livestock and humans. The first well-documented case of cardiac hydatid disease is described by Williams in 1836 .

Hydatid disease of the heart is a rare zoonosis, caused by the larvae of Echinococcus granulosus. ${ }^{1,2}$ The disease is endemic, with highest incidence in countries with well developed sheep-breeding: southern part of South America, the Mediterranean, southern part of the former USSR countries (mainly Uzbekistan), Middle East, Arabian Peninsula, North Africa, Australia, New Zealand, Kenya and Uganda. In 2013 in Europe 811 cases of hydatid disease were reported of which 794 were laboratory-confirmed. The notification level in European Union (EU) was 0.18 cases per 100000 people, which is a decrease of $5.7 \%$ compared to 2012 . The highest notification frequency was reported in Bulgaria with 3.82 cases per 100 000, along with Lithuania with 0.77 cases per 100 000. In 2013 Bulgaria reported 278 cases of hydatid disease. The notification level in Bulgaria exceeds 21 times that of the EU average. ${ }^{3}$

Main reservoir of the parasite are dogs and wild carnivores. Humans are intermediate hosts and the transmission is by ingestion of contaminated food and water and also through direct contact with infected animals. ${ }^{4,5}$ The frequency of cardiac involvement represents $0.5-2 \%$ of all forms of the disease in humans. The most commonly affected organs are the liver (55-70\%) and the lungs (18-35\%). ${ }^{6}$ Cardiac echinococcosis is usually accompanied by involvement of another organ. Isolated intracardiac location of the disease, as it is in our clinical report, is a very rare condition.

\section{CASE REPORT}

We present a case of an 18-year-old female patient 
who was admitted to the Cardiac surgery department with suspected intracardiac echinococcus cyst.

\section{HisTORY}

In May 2015 the patient was treated in a cardiology department for acute pericarditis. In June 2015 she was readmitted with chest pain, subfebrility and palpitations. During echocardiography multivesicular formation in the wall of the left ventricle was visualized. The patient was transferred to our hospital for further diagnosis and eventually surgical treatment.

Physical examination revealed nothing abnormal.

Laboratory tests (Table 1).

Coagulation test (Table 2).

Serological test ELISA-Echinococcosis (+).

Electrocardiography: Sinus rhythm, visible ST depression in I, II, III, avF, V3-V6.

Chest $X$-ray: Both lung fields seemed to be equally

Table 1. Laboratory tests

\begin{tabular}{|c|c|c|c|c|}
\hline 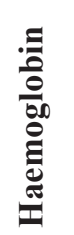 & 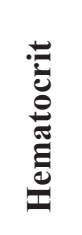 & RBC & WBC & PLT \\
\hline 125 & 0.37 & 4.36 & 9.7 & 403 \\
\hline
\end{tabular}

Table 2. Coagulation test

\begin{tabular}{cccc}
\hline PT & INR & APPT & Fibrinogen \\
\hline $111 \%$ & 1.00 & 20.5 & 2.95 \\
\hline
\end{tabular}

translucent. No evidence of infiltrative changes or pleural effusions. Hilar congestion. Cardiomegaly.

Abdominal ultrasound: Liver - no abnormalities. Folded gallbladder. Spleen, pancreas and kidneys bilaterally - without abnormalities.

Contrast enhanced CT (Figs 1-4): There were no pathological lesions in the lung parenchyma bilaterally. Cystic lesion with diameter of $60 \mathrm{~mm}$ and a double wall contour in the wall of the left ventricle was found. The finding is septated with 11 HU density.

\section{Echocardiography (Figs 5-7)}

Echocardiography revealed left ventricular ejection fraction $64 \%$. The diameter of the aortic valve ring was $2.10 \mathrm{~cm}$, the aortic root $-2.5 \mathrm{~cm}$, the ascending aorta $-2.2 \mathrm{~cm}$. The aortic valve has peak gradient of $8 \mathrm{~mm} \mathrm{Hg}$ with no signs of regurgitation. Interventricular septum $-0.8 \mathrm{~cm}$, posterior wall of LV - 0.9, LVIDd - 4.3, LVIDs - 2.7, EDV - 99 ml, ESV - $34 \mathrm{ml}$. Mitral valve - no signs of regurgitation. Tricuspid valve is with 0+-regurgitation. Normal mean PA pressure. Cystic formation was visualized, which is septated, with dimensions of $6.3 / 5.3 \mathrm{~cm}$ in the lateral wall of the left ventricle. Doppler of carotid arteries - without abnormalities.

\section{OPERATIVE TECHNIQUE}

(Figs 8-10)

Therapy with albendazol was started preoperatively.

After median sternotomy intrapericardial adhe-

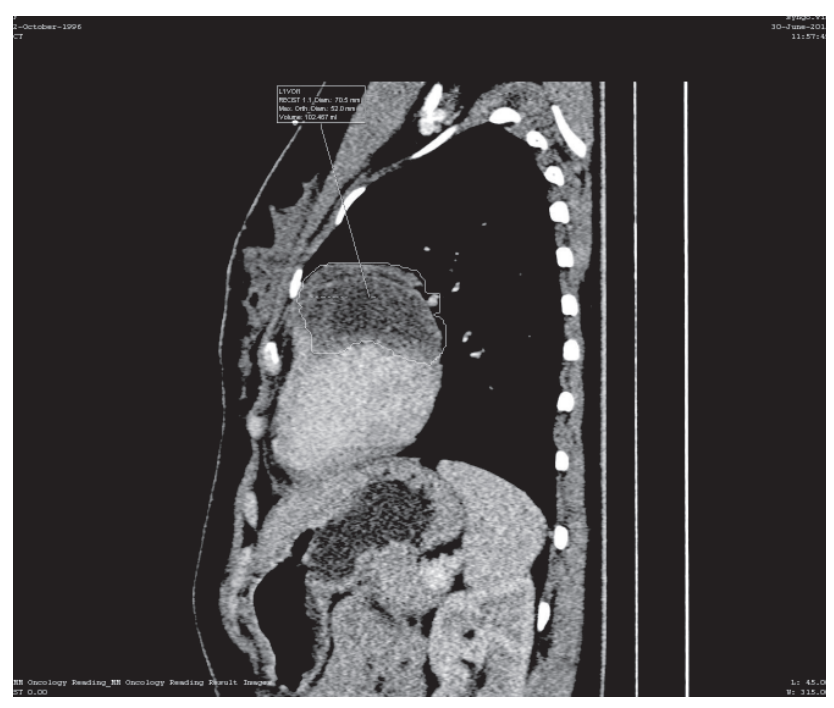

Figure 1. Preoperative contrast enhanced CT.

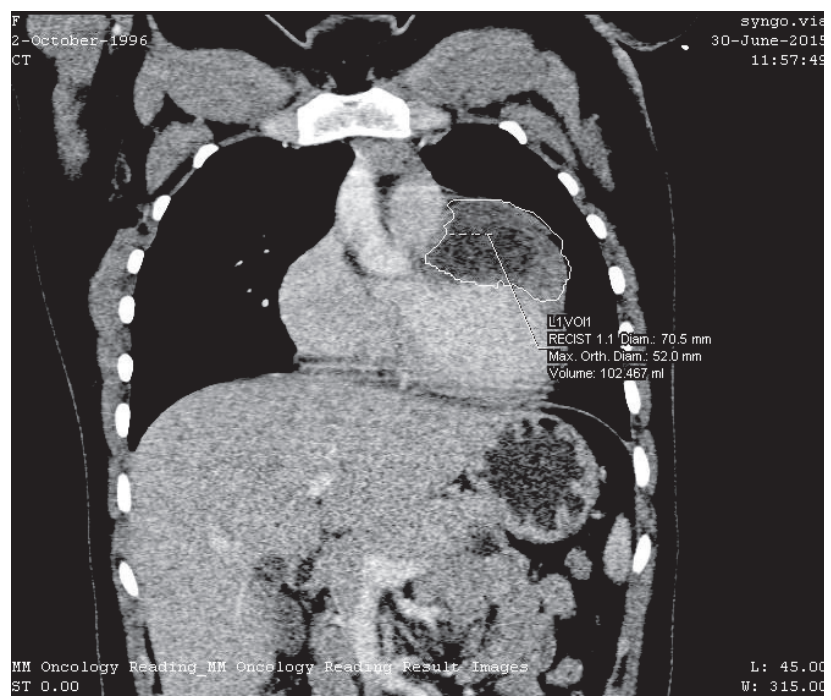

Figure 2. Preoperative contrast enhanced CT. 


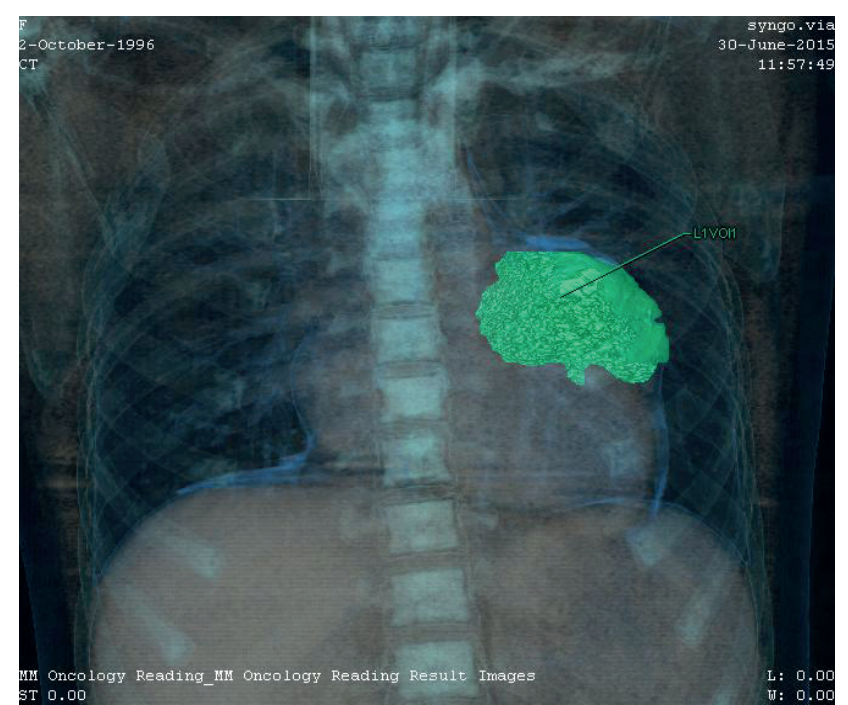

Figure 3. Preoperative contrast enhanced CT.

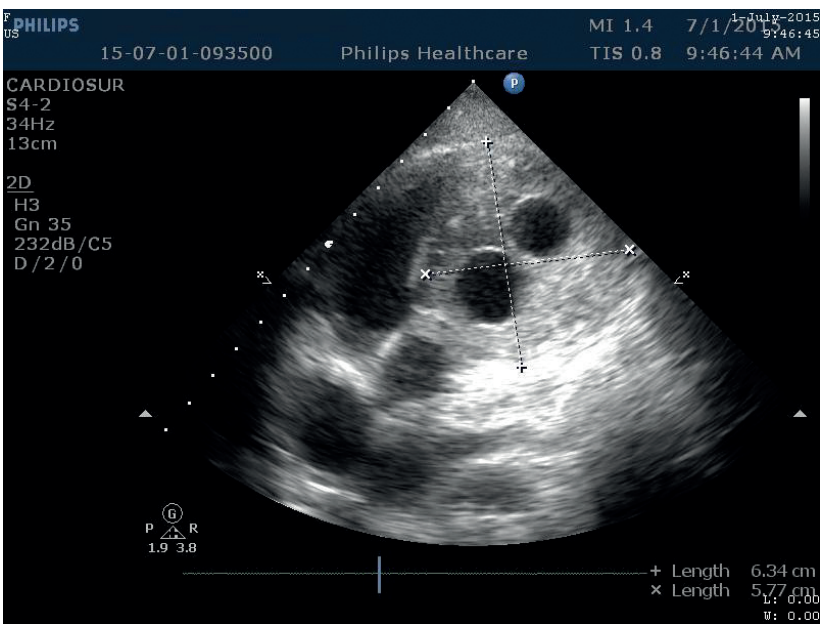

Figure 5. Preoperative echocardiography - transthoracic and transesophageal.

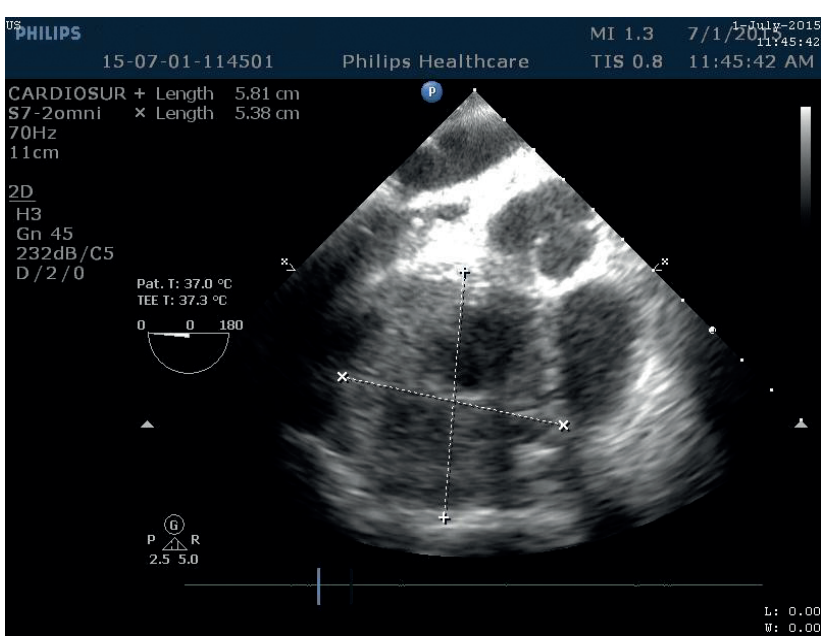

Figure 7. Preoperative echocardiography - transthoracic and transesophageal.

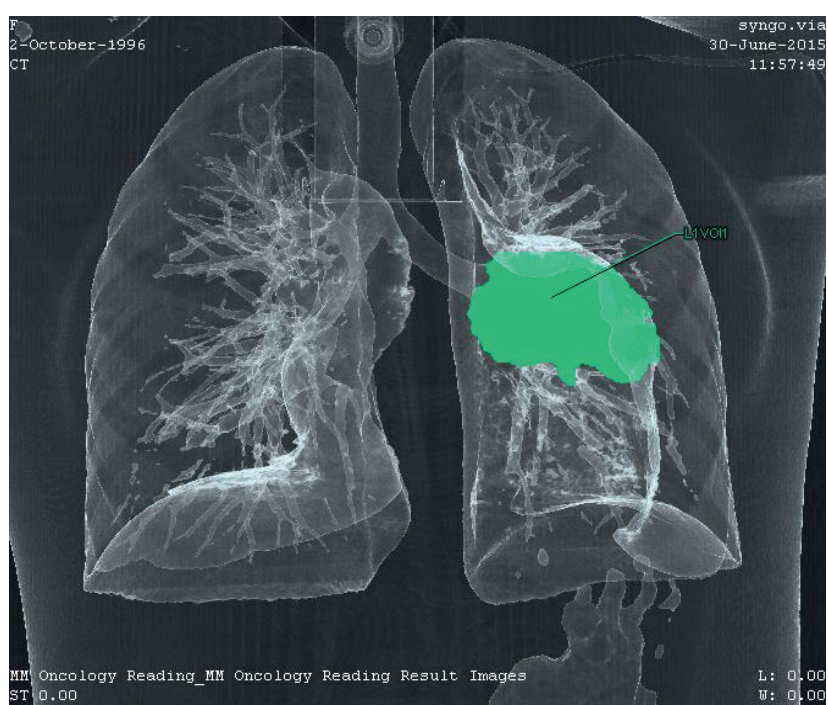

Figure 4. Preoperative contrast enhanced CT.

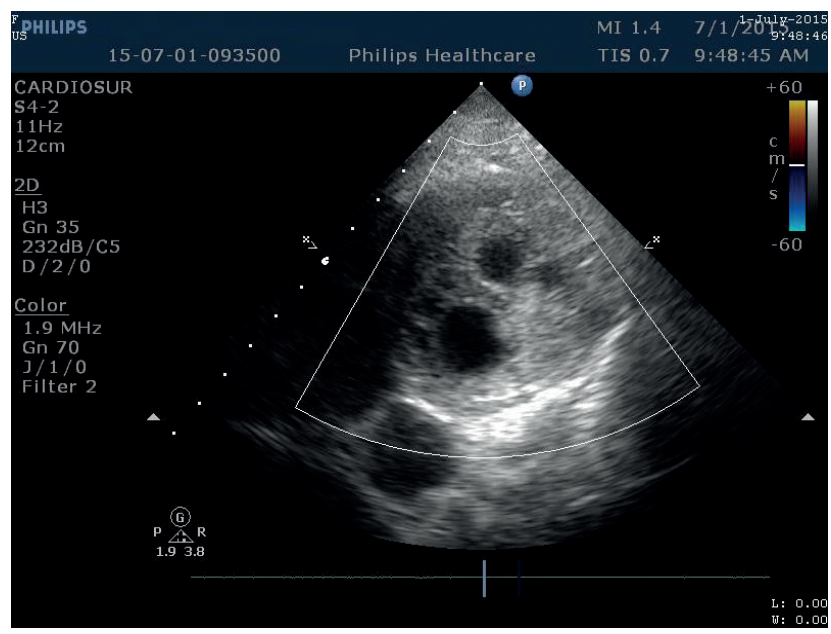

Figure 6. Preoperative echocardiography - transthoracic and transesophageal.

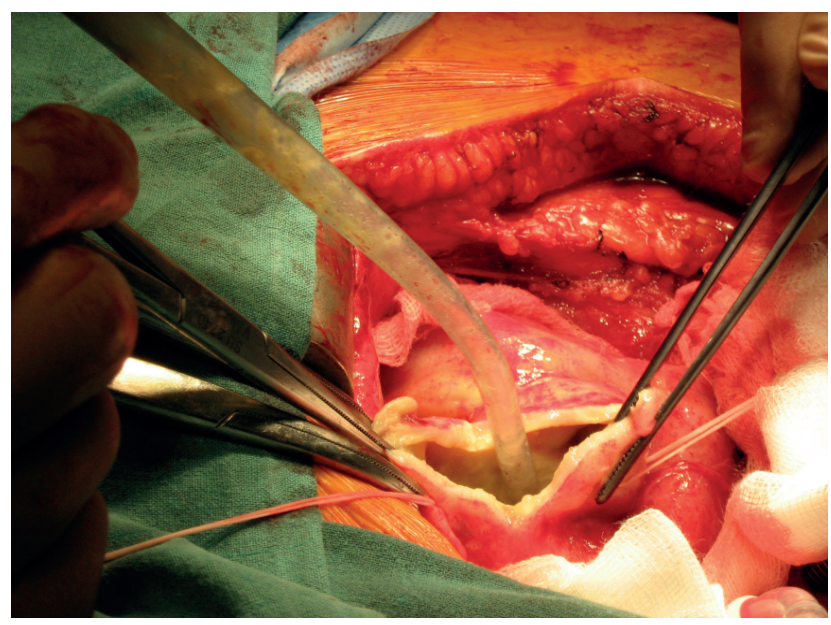

Figure 8. Cystotomy. 


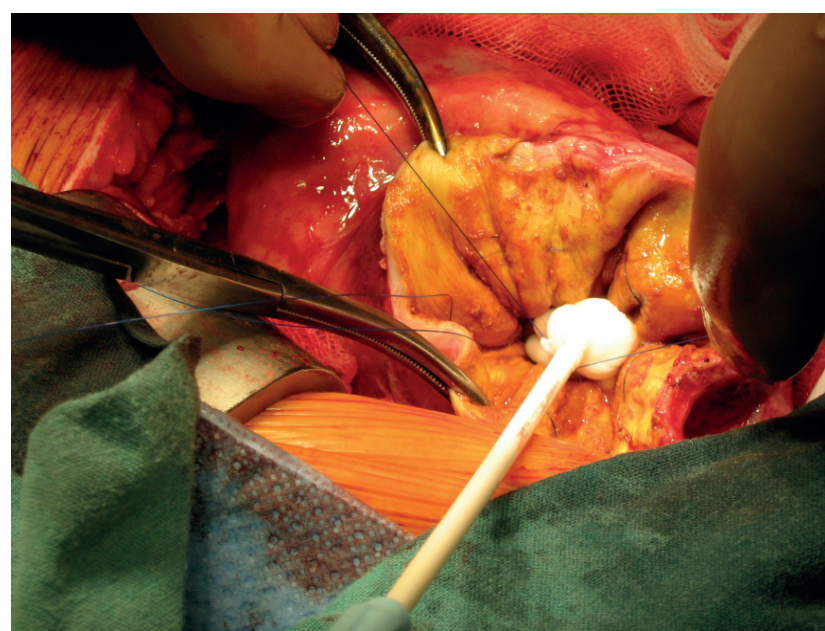

Figure 9. Cyst membrane and daughter cysts.

sions were dissected. Standard cardiopulmonary bypass through cannulation of the right atrium and the ascending aorta was established. Myocardial protection was achieved by administration of antegrade cardioplegia and mild hypotermia. The cyst was exposed, it was located intramurally in the free wall of the left ventricle. Cystotomy was performed with aspiration of pale pink liquid. A sample for histological verification was sent to the laboratory. After removing the content of the cyst, the cavity was treated by $3 \%$ hydrogen peroxide and iodinepovidone solutions. Capitonnage was completed using 4.0 prolene and gelatine tissue glue - Surgiflo. Successful weaning from extracorporeal circulation was completed without any catecholamine support. Overall time of extracorporeal circulation was 77 minutes, the aortic cross-clamp time - 54 minutes.

\section{POSTOPERATIVE PERIOD}

The early postoperative period was uneventful. On the second postoperative day the mediastinal chest tubes were removed, with overall blood loss of 390 $\mathrm{ml}$. On the third postoperative day the patient was transferred from ICU to general ward. She was discharged on POD - 10. Therapy with albendazole $400 \mathrm{mg}$ was continued for 6 months. One-year follow-up showed good postoperative outcome with no evidence of relapse of the disease.

\section{DISCUSSION}

Oncospheres that are released into the intestine, enter the portal or lymphatic circulation. Some of these oncospheres avoid the 'trap' of the liver

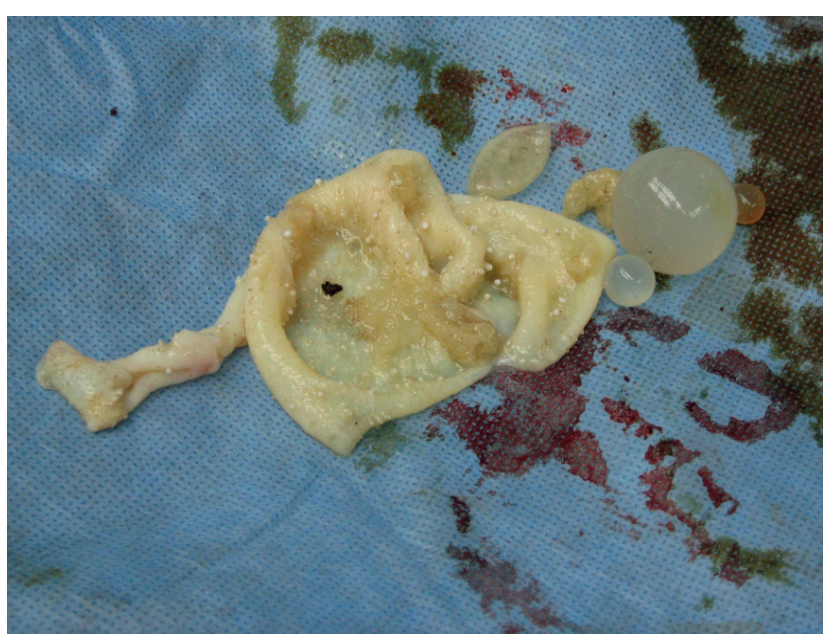

Figure 10. Cyst cappitonage.

and lungs and reach the myocardium through the coronary circulation. When this happens, they reach mainly the left ventricle $(60 \%)$, as in the clinical case described herein, the right ventricle $(15 \%)$, interventricular septum (9\%), left atrium (8\%), right atrium (4\%) and the interatrial septum $(2 \%){ }^{7-10}$ The primary pericardial cysts are extremely rare and usually develop after a rupture of myocardial cyst or contamination during surgical intervention. ${ }^{11,12}$

The myocardial echinococcosis develops towards the epicardium or endocardium. The subepicardial cysts grow easily into the pericardial cavity and can reach significant size, while those in the endocardium tend to grow into the cardiac chambers. The most severe complication of this disease is the rupture. Intrapericardial rupture of hydatid cyst develops in about $10 \%$ of the cases resulting in acute pericarditis and eventually constrictive pericarditis. ${ }^{13,14}$ During intracardiac rupture embolization in the pulmonary or systemic circulation may occur, leading to dissemination of the disease in different organs. ${ }^{15}$ The patient may develop anaphylactic reaction with severe circulatory collapse and even death may ensue. The frequency of intramyocardial perforation is high $-25-40 \%$.

Cardiac cysts often remain asymptomatic (in about $10 \%$ of cases). Patients commonly present with the following symptoms - dyspnoea, chest pain and palpitations. More rarely, there may be fever, cough, hemoptoe, allergic manifestations. Symptoms depend on the location and size of the cyst.

Diagnosis of the disease is difficult, as the period between infection and clinical manifestation is long (sometimes more than 10 years). At about $25 \%$ of 
patients there is eosinophilia, but this is a nonspecific sign. In the reported clinical case there was no eosinophilia. Echocardiography is the most valuable diagnostic method. CT, MRI, transesophageal echocardiography are used for more complicated cases. They may be helpful in defining accurate location, evaluation of the surrounding tissues and could exclude other locations of echinococcosis in other organs. Although serological diagnosis has been widely used, echocardiography has higher sensitivity in case of suspected cardiac involvement. ELISA test is most sensitive for liver localization (85-98\%), less sensitive for lung cysts (50-56\%), and the least sensitive for another location (25-56\%).

The treatment of cardiac echinococcosis begins with antihelmintic drugs, but usually surgical removal of the cyst is necessary. Albendazole and mebendazole can be used as single therapy in patients with small uncomplicated cysts, but complete regression of the disease with medical treatment is possible in only $30 \%$ of the cases. The radical surgical excision is the definitive treatment. During surgery, it is important to prevent rupture of the cyst and dissemination of the disease. For this purpose extracorporeal circulation has to be established and it is important not to handle the heart before clamping the aorta.

\section{CONCLUSION}

Hydatid disease of the heart is a rare condition. It has various clinical manifestations. The disease should always be suspected, especially in endemic areas. Due to high risk of complications, cardiac hydatid cysts must be removed surgically using extracorporeal circulation even in asymptomatic patients.

\section{REFERENCES}

1. Abu-Eshy SA. Some rare presentations of hydatid cyst (Echinococcus granulosus). J R Coll Surg Edinb 1998;43(5):347-52.

2. Brown RA, Millar AJ, Steiner Z, et al. Hydatid cyst of the pancreas - a case report in a child. Eur J Pediatr Surg 1995;5(2):121-3.

3. EFSA and ECDC (European Food Safety Authority and European Centre for Disease Prevention and Control), 2015. The European Union Summary Report on Trends and Sources of Zoonoses, Zoonotic Agents and Foodborne Outbreaks in 2013. EFSA Journal 2015;13(1):3991.

4. Blanton R. Echinococcosis. In: Behrman RE, Kliegman RM, Jenson HB, editors. Nelson Textbook of Pediatrics. 17. Philadelphia: WB Saunders Company; 2004. pp. 1173-4.

5. Pedrosa I, Saiz A, Arrazola J, et al. Hydatid disease: Radiologic and pathologic features and complications. Radiographics 2000;20:795-817.

6. WHO/OIE. Echinococcosis in humans: clinical aspects, diagnosis and treatment. In: Eckert J, Gemmell MA, Meslin FX, et al. eds. Manual on Echinococcosis in Humans and Animals: A Public Health Problem of Global Concern, World Organisation for Animal Health, Paris, France, 2001. pp. 20-66.

7. Salih OK, Celik SK, Topcuoglu MS, et al. Surgical treatment of hydatid cysts of the heart: a report of 3 cases and a review of the literature. Can J Surg 1998;41:321-7.

8. Abid A, Ben Omrane S, Kaouel K, et al. Intracavitary cardiac hydatid cyst. Cardiovasc Surg 2003;11:521-5.

9. Ozer N, Aytemir K, Kuru G, et al. Hydatid cyst of the heart as a rare cause of embolization: report of 5 cases and review of published reports. J Am Soc Echocardiogr 2001;14:299-302.

10. Kaplan M, Demirtas M, Cimen S, et al. Cardiac hydatid cysts with intracavitary expansion. Ann Thorac Surg 2001;71:1587-90.

11. Narin N, Mese T, Unal N, et al. Pericardial hydatid cyst with a fatal course. Acta Paediatr Jpn 1996;38:61-2.

12. Birincioglu CL, Bardakci H, Kucuker SA, et al. A clinical dilemma: cardiac and pericardiac echinococcosis. Ann Thorac Surg 1999;68:1290-4.

13. Di Bello R, Mantero ME, Dubra J, et al. Hydatid cyst of the left ventricle of the heart. Acute hydatid pericarditis. Am J Cardiol 1967;19:603-6.

14. DiBello R, Abo JC, Borges UL. Hydatid constrictive pericarditis. A new case and review of the literature. J Thorac Cardiovasc Surg 1970;59:530-2.

15. Pasaoglu I, Dogan R, Hazan E, et al. Right ventricular hydatid cyst causing recurrent pulmonary emboli. Eur J Cardiothorac Surg 1992;6:161-3. 


\title{
Эхинококкоз сердца с поражением миокарда левого желудочка у пациента 18-летнего возраста
}

\author{
Заприн Г. Важев, Христо А. Стоев \\ Кафедра сердечно-сосудистой хирургии, Медицинский университет - Пловдив, Пловдив, Болгария
}

Адрес для корреспонденции: Христо А. Стоев Кафедра сердечно-сосудистой хирургии, Медицинский университет Пловдив, бул.,ППещерско шосе" 66,4000, Пловдив, Болгария E-mail: hristostoev87@gmail.com Tel: +359897336168

Дата получения: 06 января 2017

Дата приемки: 26 июля 2017

Дата онлайн публикации: 25 сентября 2017

Дата публикации: 30 июня 2018

Ключевые слова: гидатидная болезнь, гидатидная болезнь сердца, эхокардиография, хирургическое лечение

Образец цитирования: Vazhev ZG, Stoev HA. Cardiac echinococcosis involving left ventricular myocardium in an 18-year-old patient. Folia Med (Plovdiv) 2018;60(2):308-13. doi: 10.1515/folmed-2017-0081
Гидатидная болезнь является одной из наиболее распространённых форм инфекций, причинённых ленточным цепнем. В основном она вызывается Echinococcus granulosus и имеет эндемическое распространение. Заражение людей, которые являются промежуточными хозяевами, происходит при проглатывании заражённой пищи и воды или при прямом контакте с инфицированными животными. Поражение сердца и миокарда встречается в исключительно редких случаях.

Нами представлен случай пациента женского пола 18-летнего возраста, принятого в отделение кардиологии с жалобами на боли в сердце и субфебрилитет. Трансторакальная эхокардиография и компьютерная томография с контрастным увеличением установили огромную, чётко организованную структуру интрамиокардиальной кисты в стенке левого желудочка и несколько дочерних кист. Диагноз эхинококкоза сердца подтвердил и серологический анализ крови - ELISA. Мы осуществили полное удаление кисты при помощи экстракорпоральной циркуляции. Послеоперационный период прошёл гладко. Был назначен приём Албендазола. Наблюдение за состоянием пациента в течение одного года установило хорошие послеоперационные результаты без признаков рецидива болезни.

Гидатидная болезнь сердца является редким заболеванием, но в то же время представляет собой опасное для жизни состояние ввиду высокой степени риска перфорации кисты. Ранние диагностика и лечения особенно важны. Эхокардиографические находки являются исключительно ценными для диагностики. Результаты хирургической эхинококкэктомии в сочетании с пероральной антигельминтной терапией после операции предпочтительны перед консервативным лечением. 